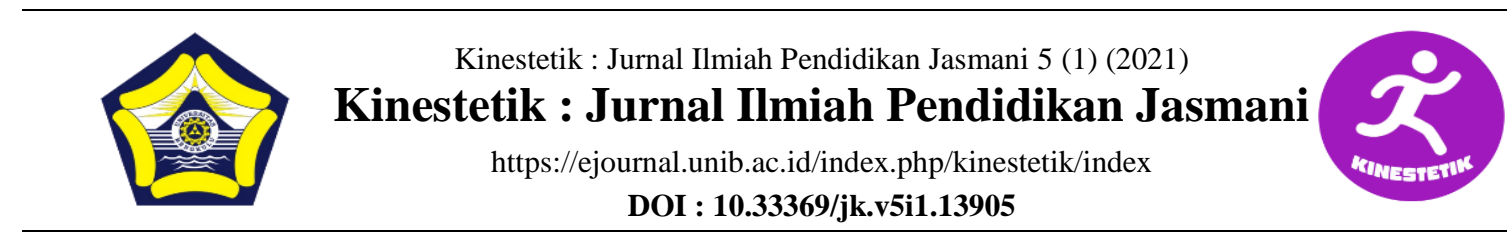

\title{
BLENDED LEARNING WITH JIGSAW IN INCREASING INTEREST, MOTIVATION, AND LEARNING OUTCOMES IN SPORTS SOCIOLOGY LEARNING
}

\author{
Yahya Eko Nopiyanto ${ }^{1}$, Ari Sutisyana ${ }^{2}$, Septian Raibowo ${ }^{3}$, Yarmani ${ }^{4}$ \\ ${ }^{1234}$ Physical Educations, Universitas Bengkulu, Bengkulu, Indonesia
}

\section{Article Info}

Article History:

Received : December 2020

Revised : January 2021

Accepted : March 2021

Available online : March

2021

\section{Keywords:}

Blended, jigsaw, interest, motivation, sociology.

\begin{abstract}
The purpose of this study was to increase the interest, motivation, and learning outcomes of students in learning sports sociology by applying blended learning with the jigsaw method. The research method used was an action classroom with two cycles. The research subjects were students of the fifth semester with a total of 39 students. The results showed that in the pre-cycle students' interest in learning was in the low category, learning motivation was in the sufficient category. The results of cycle 1 showed that interest in learning student increases in the high category with a percentage of $70 \%$, learning motivation was in the high category with a percentage of $75 \%$, learning outcomes were in the high category with a percentage of $70 \%$. The results of cycle 2 showed that student interest in learning increases in the high category with a percentage of $80 \%$, learning motivation was in the high category with a percentage of $85 \%$, learning outcomes were in the category high with a percentage of $85 \%$. So it can be concluded that the application of blended learning with the jigsaw method can increase the interest, motivation, and learning outcomes in learning sports sociology.
\end{abstract}

\footnotetext{
Corresponding address: Jln, Hibrida Kota Bengkulu, Bengkulu

*Email: yahyaekonopiyanto@unib.ac.id

ISSN 2685-6514 (Online)

ISSN 2477-331X (Print)
} 


\section{INTRODUCTION}

Blended learning is a learning model that combines face-to-face learning with online learning using learning resources e-learning (Sutopo, 2012). One of the alternative choices made by lecturers to increase effectiveness, efficiency, and greater interest in interacting between students in a heterogeneous learning environment is to use blended learning. One of the advantages of blended learning is to increase student interest in learning. With interest, students will be happy and feel challenged to take part in learning. Someone who is happy with something will be motivated to do these activities so that students who are usually passive become more active (Hamzah, 2012).

Based on the results of the study, it stated that blended learning was very effective in motivating students to participate and interact in learning activities, so that this model can improve learning outcomes (Keshta, 2013). High student motivation at the beginning of learning gets maximum learning outcomes using a blended learning (Delialioğlu, 2012). The results of the study said that learning using blended problem based learning got better results than the model problem based learning that was not combined with learning online (Lynch et al., 2013). However, face-to-face learning activities in blended learning can use various learning models according to student needs. In addition to the problembased learning model, the cooperative learning model jigsaw can also be used for face-to-face activities directly in the application of blended learning. The cooperative learning jigsaw model is a learning model that is able to provide opportunities for students to think, argue, and act actively, creatively, and innovatively in the learning process. Through this learning model, intellectual, emotional, and skills can be developed simultaneously. With this learning model, the dominance of lecturers in the learning process will effectively and efficiently reduce, so that the level of boredom of students in receiving lessons will decrease.

Based on the research results, it can be seen that learning motivation and student learning outcomes were increasing by applying the cooperative learning jigsaw model (Nopiyanto \& Raibowo, 2020). The results of other research also stated that the cooperative learning jigsaw model can increase student motivation, student learning outcomes and is more effective to be applied in the learning process compared to conventional learning methods (Budiawan \& Arsani, 2013). The cooperative learning jigsaw model can increase learning activities and learning motivation (Rosdiati, 2020). The research conducted by (Palennari, 2012) found that the cooperative learning jigsaw model can improve students' conceptual understanding and creativity.

Based on the results of observations while teaching the sports sociology course, it can be seen that: 1) $70 \%$ of students in taking lectures are passive and take notes, 2) most students cannot discuss independent assignments given by lecturers and collect these assignments not on time, c) $80 \%$ of students in learning have low motivation, this can be seen when the lecturer finishes explaining and the opportunity to ask questions or express opinions, only two people take advantage of this opportunity and the person remains the same, d) student interest in participating in learning is low because $80 \%$ students enjoy playing on their handphone while the learning process is in progress, e) there are still student learning outcomes that have not been completed.

Interest in learning has a great influence on student learning outcomes. Student interest in learning is the main 
factor that determines the degree of student learning activity. Learning interest is the constant desire of students to pay attention to and remember the learning activities they do in class (Slameto, 2010). Learning activities that are of interest to students will continue to be considered accompanied by a sense of pleasure and a sense of satisfaction obtained. To be able to foster student interest in learning in sports sociology learning is to apply blended learning with the learning jigsaw model. Based on the results of research, the learning jigsaw model can increase student interest in learning(Fajariana, 2018).

Learning motivation is the driving force in students who can foster learning activities to provide direction and learning objectives to be achieved (Sardiman, 2012). Learning models that can take advantage of current technological developments are needed so that students' learning motivation increases (Ningsih et al, 2017). Meanwhile, learning outcomes are overall changes in students which include cognitive, affective, and psychomotor aspects as a result of the learning process (Susanto, 2015). The learning outcomes referred to in this study are changes in students' cognitive, skill, and affective aspects after participating in sports sociology learning.

Based on the problems that occur in the sport sociology learning process, it takes concrete steps to improve these conditions. To the best of the author's knowledge, research on the application of blended learning and jigsaw to improve interest, motivation, and learning outcomes of sports sociology in the physical education students. This is what motivates the author to research with the title "blended learning with a jigsaw in increasing interest, motivation, and learning outcomes in sports sociology learning".

\section{METHODS}

The method used in this research was classroom action research with 2 cycles that focuses on increasing the interest, motivation, and learning outcomes of sports sociology.

\section{Participants}

Participants in this classroom action research were fifth-semester physical education students with a total of 39 students.

\section{Procedures}

The research procedures used in this study consisted of planning, actions, observing, and reflecting. The research stages are as follows.

1. Planning

a. Examine the sports sociology learning material and its indicators.

b. Develop a learning implementation plan according to the indicators through the blended learning model and jigsaw.

c. Prepare learning resources, observation sheets, questionnaires, and written tests

2. Action

The action used models blended learning and jigsaw to increase interest, motivation, and learning outcomes in sports sociology. The implementation of this study consisted of 2 cycles, each with 3 meetings per cycle. To facilitate the implementation of research actions, the researchers compiled the following learning scenarios:

a. Explain to students the instructions for implementing learning with the blended learning methods and jigsaw through the application zoom meeting. 
b. Dividing students into several groups, each group has one expert who will explain the material to a group of friends. One group of experts and several homes of groups.

c. Discuss with the expert group about the learning material, then the expert group explains to the members of the homegroup.

3. Observation

When students conduct discussions through the blended learning and jigsaw, the researcher records and observe each student's responses in the learning process. The observation stage was carried out by the researcher to observe every event during the implementation of the action using blended learning and jigsaw. Observation activities were carried out using observation sheets to determine the increase in interest, motivation, and learning outcomes of sports sociology.

\section{Refleksi}

At this stage, the researcher carries out several processes in achieving the reflection stage, namely:

\section{a. Data Analysis}

After the data recorded through the audiovisual instrument was played back, the researchers conducted a discussion with colleagues who collaborated about the results that had been obtained. Discussions include successes, failures, and obstacles encountered during an action.

b. Reducing data

The data obtained is then selected what is needed and can be used as a reference in preparing research reports.

\section{c. Arranging corrective steps}

After getting an overview of the problems and obstacles found, the next step is for the researcher to rearrange the activity plan that refers to the deficiencies found in the previous cycle so that it can get good results in the next cycle

\section{Data Analysis}

This research uses descriptive qualitative data analysis techniques. Data analysis starts from the beginning to the end of data collection. The data formed by words or sentences from the results of observations are processed into meaningful sentences and analyzed qualitatively. This data analysis was then carried out after the study was completed. The data obtained from this study is also in the form of quantitative descriptive data in the form of simple numbers obtained from the results of the calculation of the questionnaire is carried out and presented in a structured form so that it is easy to understand.

The results of the calculation of interest and motivation are grouped into five categories as follows:

Table 1. Criteria for Learning Interest and Motivation

\begin{tabular}{lll}
\hline No & Range & Category \\
\hline 1 & $86-100$ & Very high \\
\hline 2 & $70-85$ & High \\
\hline 3 & $60-69$ & Medium \\
\hline 4 & $50-59$ & Low \\
\hline 5 & $0-49$ & Very low \\
\hline
\end{tabular}

1. Determining the minimum completeness

The minimum completeness limit in this study is 65 .

2. Calculating classical completeness with the following formula:

Completeness $=\frac{X 1}{X 2} \times 100 \%$

Description:

$\mathrm{X} 1=$ total of students who completed $\mathrm{X} 2=$ total of students 
The results of the calculation of classical completeness are grouped into five categories as follows:

Table 2. Student Success Levels

\begin{tabular}{ll}
\hline Range & Category \\
\hline $86-100$ & Very high \\
\hline $70-85$ & High \\
\hline $60-69$ & Medium \\
\hline $50-59$ & Low \\
\hline $0-49$ & Very low \\
\hline
\end{tabular}

Success Indicators

Success indicators to measure the increase in interest, motivation, and student learning outcomes through blended learning and jigsaw for students are as follows:

1. The learning interest of students in participating in sports sociology through blended learning and jigsaw increases with at least good categories.

2. The learning motivation of students in participating in sports sociology learning through blended learning and jigsaw increases with good category.

3. At least $75 \%$ of students have completed individual learning outcomes of more than 75 in sports sociology learning.

\section{RESULTS}

This action research consisted of pre-cycle, cycle 1, and cycle 2. Each research result for each stage is presented in the form of a table and bar chart below. 1. Pre-cycle Results

Before taking action in cycles 1 and 2, the research team conducted observations and tests to determine the level of student interest and motivation.
The results of observations and tests in the pre-cycle can be seen in the tab below.

Table 3. Pre-cycle Results

\begin{tabular}{lll}
\hline Variable & \multicolumn{1}{c}{ Score } & \multicolumn{1}{c}{ Category } \\
\hline Interest & 59 & Low \\
\hline Motivation & 69 & Medium \\
\hline
\end{tabular}

Based on table 3 it can be seen that the interest of students in attending sociology lectures was still low with an average score of 59 with a percentage of $70 \%$, meaning 27 students have low interest in learning. Meanwhile, the students of motivation were in the medium category with a score of 69 with a percentage of $70 \%$, meaning that 27 students have medium learning motivation.

1. Results of Cycle 1

The results of cycle 1 were as follows:

Table 4. Results of Cycle 1

\begin{tabular}{lll}
\hline Variable & Score & Category \\
\hline Interest & 75 & High \\
\hline Motivation & 80 & High \\
\hline Outcomes & 75 & High \\
\hline
\end{tabular}

Based on table 4 it can be seen that there was an increase in student interest and learning motivation in attending sports sociology learning. The mean score of students' interest was 75, and has a high category with a percentage of $70 \%$, meaning that 27 students have high interest. The mean score of motivation also increased to 80 , and has a high category, with a percentage of $75 \%$, meaning that 29 students have high learning motivation. Meanwhile, the mean score of learning outcomes was 75 , in the high category, with a percentage of $70 \%$, meaning that 27 students have met the 
prerequisites for successful research.

2. Results of Cycle 2

The results of cycle 2 were as follows:

Table 5. Results of Cycle 2

\begin{tabular}{lll}
\hline Variable & Score & Category \\
\hline Interest & 80 & High \\
\hline Motivation & 85 & High \\
\hline Outcomes & 80 & High \\
\hline
\end{tabular}

Based on table 5 it can be seen that an increase in interest and motivation in sport sociology learning compared with the results in cycle 1 . The mean scores of students' interest were 80 , and have a high category with a percentage of $80 \%$, meaning that 31 students have a high interest in learning. The mean score of students motivation has also increased to 85, and have a high category, with a percentage of $85 \%$, meaning that 33 students who have high motivation. Meanwhile, the mean score of learning outcomes was 80 , in the high category, with a percentage of $85 \%$, meaning that 33 students who have met the prerequisites for successful research. To clarify the differences in research results from each cycle, a bar chart is made as below.

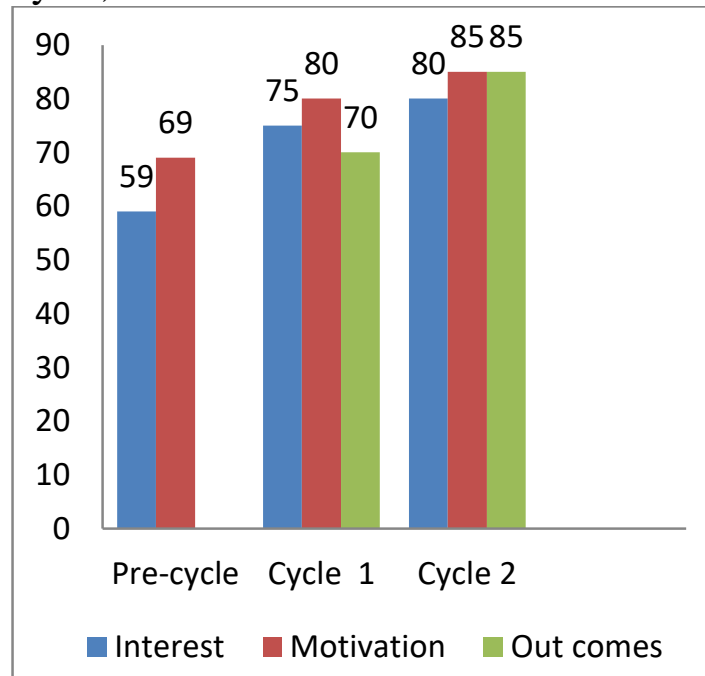

Figure 1. Bar Chart of Research Results for Each Cycle

\section{DISCUSSION}

Based on the pre-cycle results it was known that students interest were still low with a score of 59, while students motivation were in the medium category with a score of 69 . Based on the pre-cycle results, steps were needed to increase student interest and motivation in sports sociology learning, then $\mathrm{n}$ this study, two cycles were carried out. The actions in cycle 1 were carried out for 3 meetings. In cycle 1 , students were divided into 6 groups, with details of 5 original groups and 1 expert group. The learning materials in cycle 1 consist of 3 materials, namely: (1) the basic concept and position of sports sociology, (2) the sociological aspects of sports development, (3) the process of physical education in society and schools.

All learning materials in cycle 1 were prepared by the researcher on the elearning.unib.ac.id account so that each student was able to access the learning material before lectures begin in class. After all, students access and read the learning material, the researcher provides a worksheet or test to measure students' understanding of the learning material presented. From the test results, the 6 best students were selected to be the expert group whose task was to explain the learning material to the homegroup.

After the group was formed, the expert group conducts discussions through account zoom meetings with a duration of 20-30 minutes. From the results of the discussion in the expert group, the next step was for the expert group to return to the homegroup to explain the learning material, the discussion in the homegroup lasts for 30 minutes. 
The mean score of student interest in learning was 75 , and has a high category with a percentage of $70 \%$, meaning that 27 students who have high interest in learning. The mean score of student learning motivation also increased to 80 , and was in the high category, with a percentage of $75 \%$, meaning that 29 students had high learning motivation. Meanwhile, the mean score of learning outcomes was 75 , in the high category, with a percentage of $70 \%$, meaning that 27 students have met the prerequisites for successful research.

The less than optimal results in cycle 1 were due to several things including the finding of differences in perceptions between students, lack of confidence in students in delivering material to their peers, poor internet access, and there were still students who were late in entering online classes. Some of these findings agree with the results of research conducted by (Nopiyanto, 2020) which states that internet access is one of the obstacles to the online learning process. So that the deficiencies in cycle 1 must be reflected or evaluated to improve the results in cycle 2 because evaluation is a way to improve better results (Raibowo, Nopiyanto \& Muna, 2020).

The findings and research results in cycle 1 were important assets for researchers to improve optimal results. In cycle 2, students were divided into 6 groups, with details of 5 home groups and 1 expert group. The learning material in cycle 2 consists of 3 materials, namely: (1) socio-cultural dimensions in sports coaching, (2) interaction between government, private sector, and society in sports development, (3) media and the Olympic movement.
All learning materials in cycle 2 were prepared by the research team through the WhatsApp group so that each student was able to access the learning material before lectures began in class. After all, students access and read the learning material, the research team provides a worksheet or test to measure students' understanding of the learning material presented. From the test results, the 6 best students were selected to be the expert group whose task was to explain the learning material to the homegroup.

After the groups were formed, the expert group conducts class discussions with a duration of 20-30 minutes. From the results of the discussion in the expert group, the next step was for the expert group to return to the original group to explain the learning material, the discussion in the homegroup lasts for 30 minutes. After the discussion was over, the lecturer who taught the course gave feedback on the course of the discussion that had been carried out. Based on observations and tests in cycle 2, it can be seen that the mean score of student learning interest was 80 , and have a high category with a percentage of $80 \%$, meaning that 31 students have high learning interest. The mean score of student learning motivation has also increased to 85 , and has a high category, with a percentage of $85 \%$, meaning that 33 students have high learning motivation. Meanwhile, the mean score of learning outcomes was 80 , in the high category, with a percentage of $85 \%$, meaning that there were 33 students who have met the prerequisites for successful research. 
The success that was carried out in cycle 2 was due to several things including the combination of online classes and faceto-face classes. As it is known, blended learning is a learning model that combines face-to-face learning with online learning using e-learning resources (Sutopo, 2012). One of the advantages of blended learning is to increase student interest in learning. With interest, students will be happy and feel challenged to take part in learning. Someone happy with something will be motivated to do these activities so that students who are usually passive become more active (Hamzah, 2012). The results of this study were also supported by research conducted by (Keshta, 2013) which states that blended learning was very effective in motivating students to participate and interact in learning activities so that this model can improve learning outcomes.

An increase in student motivation in sports sociology learning cannot be separated from the blended learning model combined with a jigsaw. The results of this study were supported by previous research conducted by (Delialioğlu, 2012) which states that blended learning can increase learning motivation. Online learning using a cooperative approach can increase intrinsic motivation (Sulisworo, 2015).

Improved student learning outcomes can occur because the cooperative learning model jigsaw is a learning model that can provide opportunities for students to think, argue, and act actively, creatively, and innovatively in the learning process. Through this learning model, intellectual, emotional, and skills can be developed simultaneously. With this learning model, the dominance of lecturers in the learning process will effectively and efficiently reduce, so that the level of the boredom of students in receiving lessons will decrease.

Based on the research results, it can be seen that learning motivation and student learning outcomes are increasing by applying the jigsaw cooperative learning model (Nopiyanto \& Raibowo, 2020). The results of other research also stated that the cooperative learning model jigsaw can increase student motivation, student learning outcomes and is more effective to be applied in the learning process compared to conventional learning methods (Budiawan \& Arsani, 2013). The cooperative learning jigsaw model can increase learning activities and learning motivation (Rosdiati, 2020). The same research conducted by (Palennari, 2012) found that cooperative learning jigsaw can improve students' conceptual understanding and creativity.

\section{CONCLUSION}

The application of blended learning with the jigsaw method has increased the interest, motivation, and learning outcomes of Physical Education students in learning sports sociology.

\section{ACKNOWLEDGEMENT}

The research team would like to thank the Faculty of Teacher Training and Education as the funder of this research "Penelitian Peningkatan Kualitas Pembelajaran 2020", with contract number 9200/UN30.7/HK/2020.

\section{REFERENCES}

Budiawan, M. (2013). Pengaruh model pembelajaran kooperatif tipe jigsaw dan motivasi belajar terhadap prestasi belajar ilmu fisiologi olahraga. Jurnal Pendidikan Indonesia, 2(1).

Delialioğlu, Ö. (2012). Student engagement in blended learning environments with lecture-based and problem-based instructional approaches. Educational Technology and Society, 15(3), 310-322.

Endah Fajariana, D. (2018). Strategi Jigsaw Dalam Meningkatkan Minat 
Belajar Mahasiswa Pada Semester Ganjil Program Studi Manajemen STIE Kridatama Bandung tahun 2017-2018. OIKOS Jurnal Kajian Pendidikan Ekonomi Dan Ilmu Ekonomi, II, 101-109. https://doi.org/10.23969/oikos.v2i2. 1031

Hamzah. (2012). Teori Motivasi dan Pengukurannya. Jakarta: Bumi Aksara.

Keshta, A. S. (2013). The Effectiveness of a Blended Learning Program on Developing Palestinian Tenth Graders' English Writing Skills. Education Journal, 2(6), 208. https://doi.org/10.11648/j.edu.20130 206.12

Lynch, P., Holden, M. T., Foley, A., Harrington, D., \& Hussey, J. (2013). Engaging entrepreneurs with a blended problem-based learning degree program. In Cutting-Edge Technologies in Higher Education (Vol. 6, Issue PARTG). Emerald Group Publishing Limited. https://doi.org/10.1108/S20449968(2013)000006G010

Nopiyanto, Y. E., \& Raibowo, S. (2020). Penerapan model pembelajaran jigsaw untuk meningkatkan motivasi dan hasil belajar mahasiswa penjas pada mata kuliah filsafat penjas dan olahraga. Journal of Sport Education (JOPE), 2(2), 61-69.

Palennari, M. (2012). Potensi Integrasi Problem Based Learning Dengan Pembelajaran Kooperatif Jigsaw Dalam Meningkatkan. Jurnal Bionature, 13(1), 1-9.

Raibowo, S., Nopiyanto, Y. E., \& Muna, M. K. (2020). Pemahaman guru PJOK tentang standar kompetensi profesional. Journal Of Sport Education (JOPE), 2(1), 10-15.

Rosdiati. (2020). Penerapan Strategi Pembelajaran Kooperatif Model Jigsaw Dalam Meningkatkan
Prestasi Belajar. SOCIUS, 9(2), 123 133.

Sulisworo, D. (2015). The Effect of Cooperative Learning, Motivation and Information Technology Literacy to Achievement. International Journal of Learning \& Development, 4(2), 58-64. https://doi.org/10.5296/ijld.v4i2.490 8

Sutopo, A. H. (2012). Teknologi Informasi \& Komunikasi Dalam Pendidikan. Yogyakarta: Graha Ilmu. 